\section{THE POSITION OF THE SCHOOL MEDICAL SERVICE.*}

BY

Leslie Kingsford, M.D.

The School Medical Service, which was inaugurated by Parliament in 1908, has from small beginnings gradually developed into a large and important service, and in many areas is regarded as, perhaps, the most important branch of Public Health. Prior to 1908 there was no systematic inspection of children, but a few Authorities had a modified medical service to deal with a small section of the work, mainly the examination of children for Schools for Mentally or Physically Defectives.

At the commencement, though the general principles governing medical inspection were outlined by the Board of Education, the work was carried out in a tentative manner whilst Local Authorities were ascertaining the extent of the problems which the inspection of the children was bringing to light. Medical staffs were at first much too small to cope with the two groups, namely, the entrants and the leavers, originally scheduled for inspection, and it was not until some years had elapsed that the Board brought pressure to bear upon the Local Authorities to carry out their full legal requirements, whilst subsequently the Board added a third group (the intermediates) for annual inspection. The numbers of Medical Officers carrying out this work, therefore, gradually increased year by year until the outbreak of the war, after which the service was with difficulty maintained until, after the cessation of hostilities, the various officers were released from military duty. It has now further become obligatory upon Local Authorities to make provision for treatment, and to extend their medical inspection to Secondary Schools; this extension of the work has naturally rendered further increases of the staff necessary.

. At the outset Parliament was ill-advised to impose the duty of medical inspection upon Local Education Authorities instead of Local Health Authorities. The latter are responsible for all matter concerning the Public Health, including the welfare of infants and young children, whilst Education Authorities should be solely responsible for education. The opportunity was, unfortunately, Jost, and consequently there has resulted in many areas the establishment of a service entirely separate from that of the Health

* Paper read before the North-Western Schoul Sub Group, on November 11th, 1921.
Service proper. Parliament subsequently realised that an error had been committed, and sought to remedy this in the recent Ministry of Health Act by arranging that the Ministry of Health should be the responsible Government Department for looking after the health of all persons whether of school age or not. During the passage of the Bill, however, the then Minister persuaded Parliament to allow the duties connected with the supervision of the health of school children to be carried out by the Board of Education on behalf of the Minister of Health. This was a most regrettable manouvre and one reacting disadvantageously throughout the whole of the country, as until the responsibility is shouldered at headquarters by the proper department, it will be difficult to adjust matters in the local areas where the School Medical Service and the Public Health Service are quite separate. In some cases, however, even in areas where the organisations are separate, the two departments are under the same Chief Medical Officer; this, at the present time, also obtains in the case of the two Govermment Departments referred to, and no doubt tends to smoother working, but this is quite a different matter from the two services being one. That there are diffculties which would have to be met if the work were undertaken by Health or Sanitary Committees and not by Education Committees must be recognised; nor would the formation of a joint committee be entirely satisfactory if its proceedings required to be ratified by each of the main committees, but these difficulties are not insuperable. In this connection it is interesting to note that the Bradford Health Committee, acting on the advice of the Medical Officer of Health, have recently recommended to the Bradford Corporation that one Committee of the Corporation should appoint and have sole control of the whole of the medical and dental staff, with the nursing and ancillary clerical staff, on both the health and education sides, and that all the work, including that connected with Clinics, Sanatoria, Hospitals, etc., carried out by these staffs should be controlled by this Committee. The matter is, it is understood, not yet settled, but the recommendation is an excellent one. In the meantime the segregation of the School Medical Service has resulted in many areas in the School Medical Officers becoming specialised for one particular branch, and, from the very nature of things, they become, as time goes on, less and less suited for other public health posts of a different nature, though, at the sane time, 
each year of greater value to Education Committees. In the early days of the service the posts were comparatively few and candidates were numerous, as they knew that there were good prospects of obtaining, in the near future, better paid posts, such as Medical Officers of Health, and a considerable number of those then appointed eventually secured the objects of their ambition. But as the numbers of School Medical Officers throughout the country increased, and Tuberculosis Officers, Infant Welfare Officers, and Venereal Disease Medical Officers came on the scene in large numbers, the prospects of an individual School Medical Officer becoming a Medical Officer of Health became more and more remote, especially as these senior posts remained numerically about the same.

It was recently estimated that there are between 1,200 and 1,500 Medical Officers in the above categories and about 300 senior posts to which they may aspire. Perhaps 15 or 20 of these posts become vacant yearly by death or retirement. The result is that the period of probation is becoming more and more prolonged, especially when it is realised that the medical training and accessory qualifications and hospital experience may approach anything up to 10 years. By this time, the Medical Officer is at least 25 years of age, and usually older, and naturally anxious to be in a position to save some money. He applies for and secures a post as School Medical Officer, and after remaining as such for a year or two begins to realise that he has joined a service with faint prospects of advancement, whilst the salary attached is in many areas barely sufficient to live upon, and is insufficient to enable him to save anything at all unless he happens to reside with his parents. I know of School Medical Officers who have regularly, at the present time, to draw on their capital in order to live, and that quite apart from any extravagances on their part. Again, I have it on good authority that in certain parts of the country the School Medical Officers are expected to have private means.

To refer for a moment to the duties and qualifications for the post of School Medical Officer. The duties vary in accordance with the area, and whether or not'the officers devote their whole time to the school work. In large areas, whether County Boroughs or County Areas, the officers usually devote their whole time to School Madical work, but in the smaller boroughs the officers, though they may be whole-time officials, frequently spend part of their time on other Public Health duties, including Infant Welfare work, Tuberculosis work, Bacteriology, Infectious
Diseases and general Public Health; such posts naturally give the holders a better chance of promotion because of their wider experience. In addition to the duties common to all School Medical Officers, namely, the inspection of certain groups of children, some examine children for the Schools for Mentally or Physically Defectivës; others investigate infectious outbreals in schools, and others undertake refraction work, or supervise treatment at Minor Ailments or Remedial Exercises Clinics. To those whose duties are almost wholly confined to medical inspection the work naturally becomes exceedingly monotonous, and the officers in consequence endeavour to improve their prospects by applying for better posts. Those whose duties are more varied are in less haste to make a move, provided that they are in receipt of reasonable remuneration.

Medical Officers join the School Medical Service for two main reasons:-

(1) As a means of promotion to a higher post, e.g., Medical Officer of Health;

(2) As a livelihood, and because they are interested in the work.

The majority enter for the first reason, but as mentioned earlier the chances of any individual eventually becoming Medical Officer of Health are small. Those who succeed in making a livelihood out of the service are few, as the Authorities offering satisfactory prospects are by no means numerous.

The importance of the School Medical Service in relation to the future health of the community has been abundantly proved by the reports of the medical examining Boards during the war, and its value in discovering and securing treatment of defects is recognised on all hands; yet during the last year for which figures are available less than $£ 900,000$ was spent in the country on Medical Inspection and Treatment. Further, a recent analysis made by Dr. Daley, of Blackburn, the comparative expenditure on the various branches of Public Health "work showed that whilst 30 per cent. of the expenditure, was in connection with tuberculosis, 26 per cent. on infectious diseases, 15 per cent. on general sanitation, and 13 per cent. on maternity and infant welfare, only 9 per cent. was in connection with the School Medical Service-a proportion certainly too small, considering its potentialities. Is it not possible that the explanation lies in the fact that the work is, in the majority of instances, under the control of Education Authorities with interests centred in matters purely educational? If the maximum of results are to be obtained from the expenditure of time and money on the service 
it is absolutely necessary that only Medical Officers of proved clinical ability and wide experience should participate in the work.

The question naturally arises as to what should be regarded as the essential qualifications and experience.

In the first place the possession of the D.P.H. is desirable, and, for those who aim at promotion in the Public Health Service, essential, as in addition to the special knowledge thereby gained, the course trains the mind to think along the line of the causation and prevention of disease.

In the second place special experience in the diseases of childhood is essential, preferably obtained by a residential post at a Children's Hospital, whilst in addition post-graduate study should have been taken in Eye, Throat and Ear work, whether or not treatment of such cases is undertaken by the School Medical Officer. For these posts recentlymqualified candidates are obviously quite unsuitable. In addition to medical experience, discrimination, tact, and a thorough understanding of local social and industrial conditions are necessary assets in maintaining cordial relations with the teachers and securing the confidence and comoperation of the parents.

Committees should realise that the School Medical Service is at least equal in importance to other branches of the Public Health Service, and consequently ought not to be regarded in any way as the junior service from which transfers to the other branches are considered as promotions; and, further, that there is considerable loss in efficiency when, for one reason or another, the staff is constantly changing its personel. Consequently Committees should, when they have secured good officers, give them every encouragement to remain in their service.

Improvement in the service would be effected by its incorporation with the Public Health Service of the area, and it should then be possible for the officers appointed to undertake, if desired, other Public Health duties, but the standard required of officers would, of course, in this event, be somewhat higher. The system of watertight compartments which exists in some of the larger areas is inflicting a serious hardship on the Medical Officers entering the School branch of the Public Health Service. At the same time it must be realised that there are some officers who are specially interested in the work, and who would prefer to do school work and no other; in these cases there would be no difficulty in the larger areas in arranging for this.
To secure an appointment as Medical Officer of Health it is now almost essential to have had personal experience with the numerous branches, one might say specialities, of the following services: School Inspection, Tuberculosis, Welfare Work, Infectious Diseases, and Venereal Diseases. In many areas these are quite separate and distinct departments; consequently, the experience of individual members of the staff is limited, and they cannot hope to secure higher posts; the only thing that appears open to them is to qualify by taking subordinate posts in smaller boroughs where the work is combined but limited in extent, and this is what in practice is actually happening. This naturally magnifies the importance of the smaller boroughs from the promotion point of view, and, other things being equal, probably deters the best candidates from applying for the posts in the larger areas.

With regard to the salaries generally offered, these are by no means commensurate with the cost of preparation nor with the cost of living. The pre-war salary was barely sufficient to live upon, and although the medical journals have agreed not to insert advertisements for posts under $\$ 500$ a year as a commencing salary, this sum has a purchasing power of considerably less than the $£ 250$ offered in the early days of the service. The position of the offcers is, therefore, worse rather than better, and the remuneration in many areas is not sufficient to allow of the officers retaining, even with the utmost economy, the position in the social scale to which their qualifications and experience justly entitle them.

In “Public Health" for December, 1920, there was published in connection with Medical Officers holding posts under Local Authorities a scale of salaries which had been adopted by the Society of Medical Officers of Health. Since that date the Whitley Council, to which the scale was to have been submitted, has, unfortunately, broken down and has not yet been re-established, but the National Association of Local 'Government Officers which is getting out a scale of salaries for all officers in the Local Government Service, has accepted the above-mentioned scale so far as Medical Officers are concerned. It is probable that the N.A.L.G.O. scale for all officers will be shortly completed and published, and it will then be the subject for discussion by the Local Whitley Councils which, it is hoped, the Ministry of Labour will shortly succeed in setting up.

The scale, apart from its financial considerations, has this merit, that it shows that the Society of Medical Officers of Health recognise 
officially that the School Medical Service is at least on a level with and not inferior in importance to the other branches of the Public Health Service, a fact by no means yet recognised by all Local Authorities, as evidenced by the advertisements in the medical journals. The medical journals have, unfortunately, not yet adopted the scale which provides for a commencing basic salary for all junior posts of $£ 500$, with Civil Service bonus in addition. By concerted action these journals would lose no advertisements whilst at the same time they would help on a branch of the profession greatly in need of assistance.

It is the knowledge of the unfortunate prospects of many of these officials which determined a paper on these lines, and it is desirable that a note of warning should be sounded for those who contenplate entering the school branch of the Public Health Service, and in this respect the advice given by Mr. Micawber to David Copperfield appears at the present time to be particularly opportune, viz. :-

“" My other piece of advice, Copperfield,' said Mr. Micawber, 'you know. Annual income twenty pounds, annual expenditure nineteen nineteen six, result happiness. Annual income twenty pounds, annual expenditure twenty pounds ought and six, result misery. The bloom is blighted, the leaf is withered, the God of day goes down upon the dreary scene, and-and in short you are for ever floored. As I am ! If in the progress of revolving years, I could persuade myself that my blighted destiny had been a warning to you I should feel that I had not occupied another man's place in existence altogether in vain. In the case of anything turning up (of which I am rather confident) I shall be extremely happy if it should be in my power to improve your prospects.' "'

I do not know whether all Public Health Officers are equally confident of something turning up from the Society of Medical Officers of Health, but none, more anxiously await it than the Dr. Micawbers of the School Medical Service.

\section{SCHOOL MEDICAL SERVICE AND THE MINISTRY OF HEALTH. \\ By a SchoOl Medical OFFICER.}

In a passage in his Republic, in which he ditcusses the cohesion of the ideal state, Plato opens his argument with the question "Shall we begin by asking ourselves what ought to be the chief aim of the legislator in the organtsation of the state?" He immediately follows this question with another. "Can there be any greater evil than discord and plurality where unity ought to reign?" It was in order to secure this unity where plurality had'existed that the Ministry of Health was created. As a means to that end it was enacted that there shall be transferred to the Minister all the powers and duties of the Board of Education with respect to the medical inspection and treatment of children and young persons ".... provided that for the purpose of facilitating the effective exercise and performance of these powers and duties, the $M$ inister may make arrangements with the Board cf Education respecting the submission and approval of schemes of local educational authorities and the payment of grants."

Now the history of this clause is of considerable unterest in the light of subsequent events.

In the Ministry of Health Bill as introduced by Dr. Addison, supported by Mr. Fisher, Major Astor and others, Clause 3 (a) proposed the transference of medical inspection and treat. ment of school children to the Ministry of Health. When the Bill was before Standing Committee A (I8th March, 1919) an attempt was made to amend this clause out of the Bill. This attempt was frustrated, and despite this opposition, Mr. Locker Lampson's amendment was agreed upon without a division, which in the words of the School Government Chronicle (coth March, p. I53), made immediate and absolute what had (in the original draft) been perrissive and deferred."

On gth April, Dr. Addison, moving an amendment to facilitate the payment of grants, stated that his proposal was a temporary measure only to tide over the period of transference. He said: "We have chdeavoured to secure to the 'Minister of Health the responsibility' which the Committee wished to attach to him directly in respect of medical inspection and treatment, and at the same time to set out arrangements which would make the formulation of schemes and the -determination of grants thereon possible of continuance upon the same lines upon which they have been found workable." Here is a definite and unequivocal acknowledgment of the determination of Parliament that, save for an interdepartmental arrangement for the 